UDC 372.881.1

DOI https://doi.org/10.24919/2308-4863/41-3-42

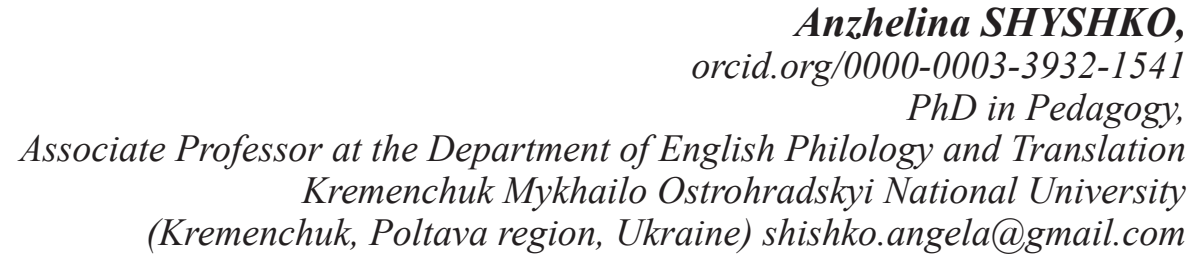

Halyna LUKANSKA, orcid.org/0000-0001-8990-8573

Senior Lecturer at the Department of Social Work and Language Training Kremenchuk Institute of Alfred Nobel University (Kremenchuk, Poltava region, Ukraine) galinamalcko@gmail.com

\title{
SYNCHRONOUS AND ASYNCHRONOUS E-LEARNING TECHNOLOGY INSTRUMENTS FOR FOREIGN LANGUAGE DISTANCE LEARNING
}

\begin{abstract}
The article deals with the study of foreign languages distance learning peculiarities, in particular, implementation of synchronous and asynchronous E-learning technology instruments, approaches to their definitions, advantages and disadvantages. The topicality of this research is predetermined by the urgent necessity to reform the Ukrainian system of education considering the current requirements. In the result of the research conducted it has been established that traditional distance and e-distance learning are the most actively used models of the modern Ukrainian educational process. However, due to the number of advantages and possibilities the form of blended learning is getting more widespread. Availability and popularity of these forms is explained by the factors that have favourable effect on the process of foreign languages learning and its efficiency (opportunity of individual choice, possibility of self-control, cooperation etc.). One of the main functions, realized by a teacher, is the function of control that is embodied during distance learning by the test, education, development and forming functions. Types of control are distinguished also by the temporal signs (diagnostic, current, periodic and final). The most common control methods during any foreign language distance learning have been presented basing on the above-mentioned data. Having studied theoretical and practical aspects of this form of learning the main criteria for choosing the means of e-learning organizing to make them maximally effective, motivating and interesting for students have been defined. Taking into consideration the experience of teachers at the current stage of e-systems implementation the most popular among them according to some criteria have been identified and specific instrument and applications to make the process of learning more successful, productive and comfortable have been proposed.

Key words: traditional distance learning, e-distance learning, distance learning technologies, synchronous and asynchronous instruments, types of control, blended learning.
\end{abstract}

Анжеліна ШИШКО,
огсіd.org/0000-0003-3932-1541
кандидат педагогічних наук,
доцент кафедри англійської філологї̈ та перекладу
Кременчуцького національного університету імені Михайла Остроградського
(Кременчук, Полтавська область, Украӥна) shishko.angela@gmail.com

Галина ЛУКАНСЬКА, orcid.org/0000-0001-8990-8573 старший викладач кафедри сочіальної роботи та мовної підготовки Кременчуиького інституту Вищого навчального закладу «Університет імені Альфреда Нобеля» (Кременчук, Полтавська область, Україна) galinamalcko@gmail.com

\section{СИНХРОННІ ТА АСИНХРОННІ ІНСТРУМЕНТИ ТЕХНОЛОГІЇ ЕЛЕКТРОННОГО НАВЧАННЯ ПІД ЧАС ДИСТАНЦЙНОГО ВИВЧЕННЯ ІНОЗЕМНОЇ МОВИ}

Стаття присвячена дослідженню особливостей вивчення іноземних мов в умовах дистанційного навчання, зокрема, впровадження синхронних та асинхронних інструментів електронної технологї̈ навчання, підходів до 
їх визначення, переваг та недоліків. Актуальність даного дослідження зумовлена нагальною потребою реформування украӥнської освітньої системи з урахуванням вимог сучасності. Встановлено, шьо найбільш вживаними моделями сучасного освітнього процесу Украӥни є традиційне дистанційне та електронно-дистанційне навчання. Однак, зважаючи на ряд та переваг та можливостей, все більшого поширення набуває змішана форма навчання. Наявність та популярність цих форм пояснюється чинниками, які сприятливо впливають на проиес вивчення іноземних мов та його ефективність (можливість індивідуального вибору, самоконтролю, співпраці тошьо). Однією з основних функцій, щзо реалізується викладачем, є функиія контролю, яка під час дистаниійного навчання втілюється тестувальною, виховною, розвиваючою та формуючою функиією. Види контролю виокремлюють за часовими ознаками (діагностуючий, поточний, періодичний та підсумковий). На основі вищезазначених даних були представлені найпоширенімі методи контролю під час дистанційного навчання іноземної мови. Вивчивши теоретичні та практичні аспекти иієї форми навчання, визначено основні критерії вибору засобів організації електронного навчання для досягнення їх максимальної ефективності, вмотивованості та ичікавості для студентів. 3 урахуванням досвіду викладачів на сучасному етапі впровадження електронних систем були визначені найпопулярніші серед них за певними критеріями та запропоновано конкретні інструменти та додатки для того, щзоб зробити процес навчання більш успішним, продуктивним та комфортним.

Ключові слова: традичійна форма дистаниійного навчання, електронна форма дистаниійного навчання, технологї дистанційного навчання, синхронні та асинхронні інструменти, типи контролю, змішане навчання.

Introduction. In recent decades, the use of technology and multimedia for learning foreign languages, including distance learning, has expanded significantly, mainly due to the desire of students to acquire knowledge, despite the time and space constraints. Therefore, the support of distance learning, the accumulation of pedagogical and methodological experience for its further development by both public and private educational organizations and institutions around the world has become extremely important. Ukraine is not an exception, and recent developments and challenges faced by the educational system at all levels clearly demonstrate the urgent need to implement appropriate reforms for distance and innovative learning that meet modern requirements and ensure the implementation of basic educational programs with high efficiency.

Related works and research analysis. The works of both foreign and domestic scientists, in particular such as J. Adams, F. Bodendorf, S. Thorne, M. Burns, J. Payne, Yunsheng Zhong, V. Egorov, V. Khrapchenkov, G. Hoppe, J. Kettunen, A. Andreeva, V. Vashchenko, K. Kolos, V. Kuklev, V. Bykov, V. Kuharenko, V. Rybalko, N. Syrotenko, I. Robert and others, are devoted to the study of theoretical and practical aspects of distance learning.

There are many approaches and interpretations of the term «distance learning». For example, according to the Ukrainian Pedagogical Dictionary, «distance learning is a form of learning when communication between a lecturer and a student or a teacher and a pupil takes place through correspondence, tape, audio and video cassettes, computer networks, cable and satellite television, telephone or fax, etc» (Honcharenko, 1997).

I. Robert defines the term «distance learning» as a process of interactive cooperation between a student, a teacher and an interactive source of information, during which knowledge, skills and competences are transferred, that is carried out in the conditions of information and communication technologies implementation (Robert, 2014).

So, having analyzed the available author's definitions and definitions from dictionaries, we can make the conclusion that the main components of the distance learning concept are the subjects of the process, the components of the educational process (learning tools, organizational and control methods) and means of information and communication technologies.

At present moment two models of distance learning organization are widely used in the Ukrainian educational process. They are defined by V. Bykov as traditional distance learning (the process that is carried out mostly asynchronously in time and is implemented by the provision of educational materials by mail or telephone) and e-distance learning (the process that is carried out both asynchronously and synchronously, the subjects of the process communicate and exchange educational materials exclusively by means of information and communication technologies (Bykov, 2009).

The most popular online educational areas at the moment are the following: IT-Education (Study of Programming, Data Science, Project Management, Tester Courses), creative professions, Marketing (SMM, SEO etc.), Sales and Motivational Courses for Entrepreneurs, Personal Development and Foreign Languages (27 Best Online Learning Platforms, 2020).

The purpose of the research. Taking into consideration special relevance of distance learning in the contemporary Ukrainian educational process, the purpose of the work is to study the main peculiarities of its traditional and e-distance learning models, to investigate its available technologies and tools, to analyze the level of its main educational functions realization and suggest the most appropriate resources to 
make the process of foreign language learning more successful, productive and comfortable.

Presentation of the main material. Distance learning technologies represent a variety of new opportunities for foreign languages teaching and allow to expand teaching methods significantly. However, it is important to review these distance learning options for ability levels, as these systems may create different constraints on the learning process. Thus, in particular, the lack of direct bilateral interaction, that is characteristic to many distance educational programs, contradicts the goals of foreign language teaching, while the use of this interaction can create its integrity (for example, strategies that encourage student-teacher dialogue and student autonomy).

Numerous electronic devices, platforms, many social networks (Viber, Skype, WhatsApp), applications (Google Duo, Google Meet, Zoom, etc.) facilitating distance learning are the main means of e-learning, and the content, technology and services are the three key sectors of modern education. For example, in case of foreign language learning, computer-based programs provide multimedia sounds, videos, graphics, and texts that allow students to delve into the target language and culture.

E-learning technology instruments are divided into two big groups - synchronous (chats, ICQ, SKYPE, interactive boards, video conferencing, etc.) and asynchronous (email, blogs, forums, Twitter, video and audio podcasts, online testing) (UDL System, 2020).

The advantages of online synchronous communication include:

1) personal contact with students;

2) direct voice contact in distance learning courses;

3) spontaneity and insight of language similar to the real environment;

4) providing timely support for voice communication by the means of instant feedback from the audience and management;

5) immediacy, operational collaboration and personal contacts.

Among the disadvantages of communication of this type we have to mention the following owns:

1) fragmentation of the educational process (students may appear in the situations distracting their attention);

2) limited communication time (not enough time for reflection);

3) the possibility of the problem with planning among people who live in different time zones or who are working;

4) the possibility of the need for additional software installation (Thorne S., Payne J., 2005).
The advantages of online asynchronous communication are:

1) additional time and opportunity to consider the decision and think over the answer;

2) the opportunity for full participation in the communication process at any time;

3) the speed of speech can be changed, and students with different language skills can be easily involved in the process of learning;

4) the participants of the interaction do not depend on time, place and the planning process;

5 ) the sense of comfort while communicating in writing.

However, it should be noted that the disadvantages in this case are the following factors:

1) the participants feel the lack of personal contact and verbal communication;

2) group decision-making requires a longer period of time;

3) the feedback can be delayed for several days or hours (Thorne S., Payne J., 2005).

The use of Internet technologies in the process of distance learning has a number of positive aspects that can significantly increase the motivation of students - they can strengthen their communication competence, get acquainted with different cultures and improve their necessary skills, such as listening, speaking, reading and writing.

We should also mention an important psychological aspect - during distance learning the level of anxiety decreases, responses are given quickly, and students become more confident. As a result, the use of distance learning helps students to acquire skills of independent work, creates comfortable conditions for creativity, increases creative and intellectual potential through self-organization, improves the ability to imply computer technology and make responsible decisions, creates favorable conditions for taking into account the individual characteristics of creative self-expression in the process of learning and for the development of personality (Lukashenko I., Lutsenko O., 2016).

The choice of the specific distance learning tools belongs to teachers, who, as a rule, try to integrate the Internet with their learning materials and learning styles to create a meaningful learning environment. For example, emails and chats are an important part of communication between students and teachers that also improve writing skills in the language learning process.

Students have the opportunity to increase their accuracy and free autonomous work via the Internet, with some favorable factors influencing this process (Fig. 1). 


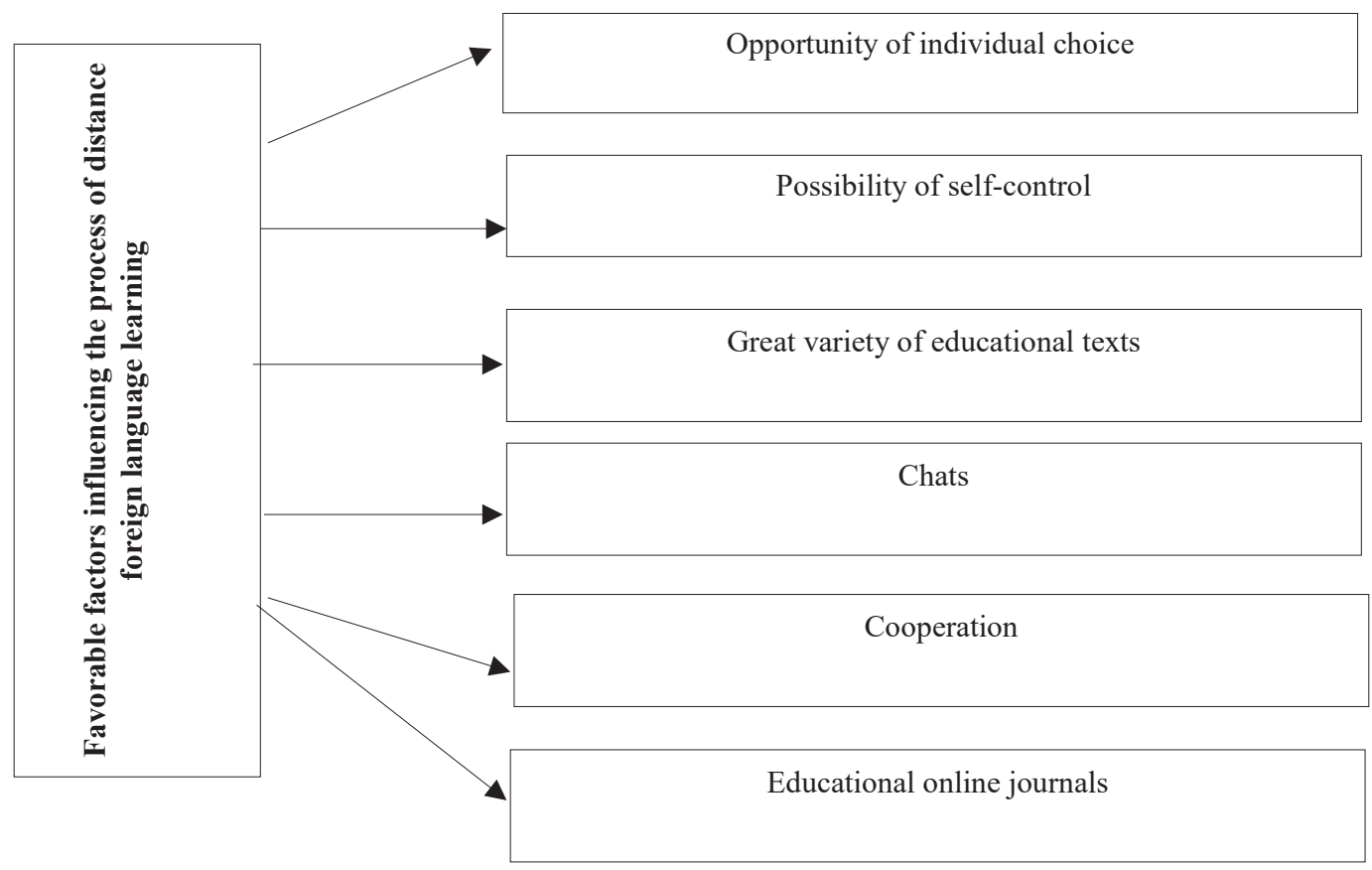

Fig. 1. Favorable factors influencing the process of distance foreign language learning

All of them positively affect the process of education and its results in different ways. For example, while using the Internet, students have the opportunity to choose their own methods, teaching materials, depth and complexity of their study basing on their individual preferences, abilities, strengths and weaknesses. Websites and online journals for learning English provide a large number of texts for listening, speaking, reading and writing. Self-control and cooperation contribute to not only academic achievements but also to the development of some useful personal skills, such as responsibility, self-awareness and socialization. The implementation of real chats in the process of learning stimulates students' communicative skills, improving their grammar and enlarging vocabulary simultaneously (Yunsheng Zhong, 2008).

At the same time, one of the most important functions performed by the teacher is the function of control - to test the knowledge, competencies and skills in the subject studied, which students receive both in class and outside it (Egorov V., Skibitsky E., Khrapchenkov V., 2008). For this purpose, distance learning courses using various forms, types and methods of control have been created. Control over the educational and cognitive activities of learners in advanced distance learning courses is aimed at both control by the teacher and the self-control of the students themselves.

During distance learning of a foreign language control is realized by the number of functions which are presented in Fig. 2 and are further explained in the article. All of them are characterized by certain features and peculiarities. For example, testing function shows learning outcomes of the students and makes their assessment. The specifics of educational function lies in the fact that it is achieved by means of memory, consolidation, clarification, refreshing of the knowledge acquired. The function of development plays a major role in the cultivation of the student's personality, his/her cognitive abilities, concentration, memory, thinking, imagination. The importance of the function of formation is explained by the idea that it provides disciplining of the students work, increasing the sense of responsibility for their work, stimulating a serious attitude to it.

Usually the types of control are distinguished by the temporal signs - diagnostic, current, periodic and final (KukharenkoV., Rybalko O., Syrotenko N., 2002).

Diagnostic control during distance learning of foreign languages is carried out with the help of «placement tests» that allow to determine the initial level of students preparation in order to study the allowable complexity of the proposed educational content. The analysis of preliminary control data also allows the teacher to make changes to distance learning courses with an emphasis on the student's foreign language knowledge (KukharenkoV., Rybalko O., Syrotenko N., 2002).

Current control enables obtaining constant information about the progress and quality of the learning material, to make changes in the learning process in 


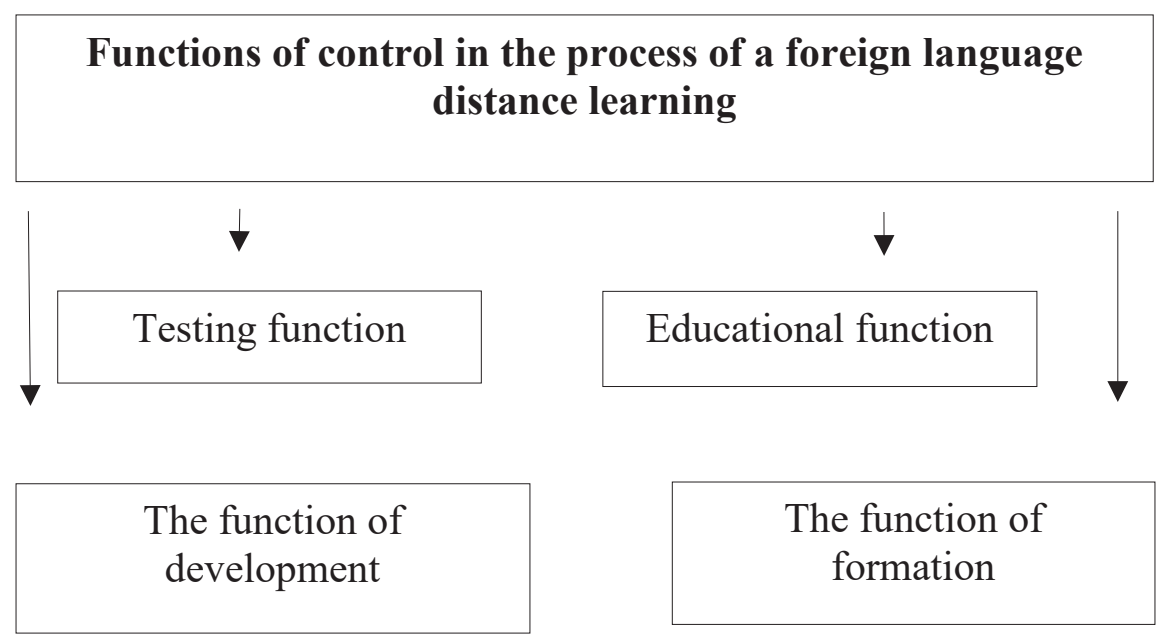

Fig. 2. Functions of control in the process of a foreign language distance learning

a timely manner. In fact, current control in advanced distance learning courses is not just an inspection it's an education, as it is related to the consolidation, review and analysis of the educational material. Periodic control allows to determine the quality of the educational material on the subject. It is conducted in the form of tests during the term or credits at the end of the term for courses, the final control of which is an exam. Final control is used to reflect the final results of the educational process in the subject, which is implemented in the form of tests or exams (KukharenkoV., Rybalko O., Syrotenko N., 2002).

Methods of control allow to determine the progress in the educational and cognitive activities of students, as well as the pedagogical work of the teacher. Testing knowledge during distance learning is a very special process that requires special attention, knowledge and peculiar skills of a teacher.

The most common control methods during any foreign language distance learning in the vast majority of the existing developed courses are the following: reading, translating the text and completing the tasks connected with it; listening and performing the tasks after listening to the relevant audio or video material; grammar tasks (in the form of tests, exercises or communicative activities); speaking on a certain topic (spontaneous speech or preparation of presentations / projects on the proposed topic); essay writing (UDL System, 2020).

It is worth noting that improving the quality of control in the use of distance learning of a foreign language can not only increase the effectiveness of education, but also motivate students to further selfdevelopment.

However, it should be noted that the effectiveness of e-learning depends on the technology used in it, and which ensures the maximum possible effective- ness of the teacher-student interaction within the system of such education. In this case the choice of electronic learning environment that provides the organization of the educational process is of great importance for distance education arrangement (Sviatskyi V., Skrypnik O., 2014). The main criteria for choosing the means of e-learning organizing include the following ones:

1) functionality (determines the availability in the system of such components as a course, conference, forum, task, test, user management, electronic dean's office, etc.);

2) cost (consists of the cost of purchasing a distance education system (with or without restrictions on the number of licenses for students) and / or development and implementation of the own distance education system, as well as the cost of hardware and telecommunications services, the cost of educational content developing and its support, the cost of providing technical support for teachers and students, etc.);

3) reliability (characterizes the convenience of administration, ease of the training material preparation and control measures, protection of the system from unauthorized access);

4) modularity (allows to expand the software basis of e-learning elements by the means of the educational institution's own and / or the third-party production);

5) stability (means the degree of trouble-free operation of the system in relation to different modes of operation and the degree of activity of users);

6) presence (or absence) of national localization of the product (means that localized version of the product is more suitable both for the administration, development and maintenance of educational materials, and for the end users of educational services);

7) support for e-learning exchange standards (in particular deals with SCORM, which is the basis of 
international exchange of electronic courses, increases the mobility of the distance learning system, enables creation of courses that can be transferred between different learning platforms and so on);

8) availability of tools for the development of educational and methodological complexes (facilitates development, allows to integrate in a single view educational material for different purposes);

9) knowledge testing system (allows online assessment of students' knowledge);

10) convenience of use (is explained by lack of redundancy, clarity of the learning process, consistency of training components, availability of assistance and technical support, etc.);

11) providing access (creates no barriers to accessing the training course related to location in time and space, limited body functions, impaired vision; using technologies that are supported by a limited range of software, etc.);

12) multimedia (provides an opportunity to use not only text, hypertext and graphic files, but also audio, video, animation, 3D graphics, etc.);

13) scalability and extensibility (is related to the possibility of expanding both the circle of students and adding training courses);

14) prospects for platform development (is guaranteed by the fact that distance learning support system should be an environment that is constantly updated, with new, improved versions, with support for new technologies, standards and tools);

15) cross-platform (means that distance learning system should not be tied to any operating system or environment at either the server level or the client machine level; users have to use standard training tools without downloading any additional modules, programs, etc.);

16) technical support quality (is realized by the ability to maintain performance, stability, troubleshooting and vulnerabilities with the involvement of specialists from the developer of the e-learning system, as well as specialists from their own support service) (Sviatskyi V., Skrypnik O., 2014).

Conclusions. Making the conclusion, we have to underline that there are a number of key differences between traditional foreign language learning and distance learning that must be taken into account while planning the educational process. In the traditional form of language learning, the teacher is the authority and the active part of the group, students usually play a passive role. The elements of traditional learning are always represented by competition in a group, standard learning for all, a specific time and place for learning, one-way learning (a teacher - a student). However, in distance e-learning the emphasis is put on the workload and application of the acquired knowledge, a special curriculum that meets the individual abilities and specific needs of a group of students (Zhukovska, 2020).

Analysis of the 2020-2021 educational institutions reports and study of teachers experience exchange in the sphere of electronic systems implementation in the process of distance learning allows us to claim that the most popular, effective and available are the following: Moodle (including Unicheck), Google Classroom, Microsoft Teams, Zoom, Hangouts and Skype. Among the main criteria for choosing these systems, specialists mention their functionality, reliability, ease of use and convenience (The Top 6 Trends in Education for 2020, 2019).

The Internet made education more popular and available and currently the specialists are searching for new, more successful, effective and comfortable approaches to the learning process to diversify, modernize and optimize it. In this regard, such instruments and methods as applications and chatbots, VR/ AR-Formats, gamifications of educational process, microlearning, personalization and adaptive learning are becoming increasingly popular and widespread.

The results of the research conducted allow to affirm that blended education is a current effective and prospective type of learning. To make it really productive it is important to combine properly different approaches, ways of presenting material and types of activities. The number of universities and other educational establishments applying this form of education in the world and in Ukraine in particular is constantly growing. According to the recent survey of the Projector Creative School and DigData Company, $56 \%$ of Ukrainians prefer the combination of the online and offline formats within one course, the third part of the people surveyed chooses online one and only $17 \%$ of them - online form (Korotenko, 2020).

Therefore, we can say that the application of distance learning in educational programs is no longer a problematic issue. At the current moment this problem has been almost solved thanks to a number of modern sophisticated tools for synchronous and asynchronous communication, which are improving every day and can meet the needs and interests of both teachers and students.

However, we should not forget that only a combination of pedagogical skills, compliance with the basic criteria for choosing the means of organization, taking into account various individual characteristics of students, adherence to the principles of mutual understanding, respect and cooperation makes the implementation of any foreign language distance learning really successful, highly effective and efficient. 


\section{BIBLIOGRAPHY}

1. Биков В. Ю. Моделі організаційних систем відкритої освіти. Київ : Атіка, 2009. 684 с.

2. Егоров В. В., Скибицкий Э. Г., Храпченков В. Г. Педагогика высшей школы. Новосибирск : САФБД, 2008. $260 \mathrm{c}$.

3. Гончаренко С. Український педагогічний словник. Київ : Либідь, 1997. 375 с.

4. Жуковська Е. ТОП-3 системи для онлайн-навчання. URL: https://osvita.ua/news/71748/ (дата звернення: 22.02.2021).

5. Коротенко О. Онлайн-освіта: як здобувати знання в епоху діджиталізації. URL: https://bazilik.media/onlajnosvita-iak-zdobuvaty-znannia-v-epokhu-didzhytalizatsii/ (дата звернення: 21.02.2021).

6. Кухаренко В. М., Рибалко О. В., Сиротенко Н. Г. Дистанційне навчання: умови застосування. Дистанційний курс: навч. посіб. Харків : НТУ «ХПІ», «Торсінг», 2002. 320 с.

7. Лукашенко I. М., Луценко О. Л. Психологічні аспекти навчання у віртуальному середовищі. Платформа кіберпсихології Arki Group. URL: https://arki.group/ua/publications/psychological-aspects-of-learning-in-the-virtual-environment/ (дата звернення: 03.02.2021).

8. Роберт И. В. Теория и методика информатизации образования (психолого-педагогический и технологический аспекты). М. : БИНОМ. Лаборатория знаний. 2014. 398 с.

9. Свяцький В. В., Скрипнік О. В. Критерії вибору засобів організації системи дистанційного навчання. Trends of modern science - 2014. Materials of the X International scientific and practical conference. May 30 - June 7, 2014. Sheffield : Science and Education Ltd., 2014. Volume 25. Modern information technologies. P. 53-55.

10. The Top 6 Trends in Education for 2020. URL: https://www.kajeet.net/the-top-6-trends-in-education-for-2020/ (дата звернення: 26.02.2021).

11. Українська Система Дистанційного Навчання. UDL System: Ukrainian Distance Learning System. URL: http://www.udl.org.ua (дата звернення: 22.03.2021).

12. Thorne S. L., Payne J. S. Evolutionary Trajectories, Internet-mediated Expressions and Language Education. $C A L-$ ICO Journal. No 22, 2005. pp. 371-397.

13. Yunsheng Zhong. A Study of Autonomy English Learning on the Internet. English Language Training. Vol. 1. No. 2, 2008. pp. 147-150 pp.

14. 27 Best Online Learning Platforms. URL: https://www.learnworlds.com/online-learning-platforms (accessed 24 March 2021).

\section{REFERENCES}

1. Bykov V. Yu. Modeli orhanizatsiinykh system vidkrytoi osvity [Models of the open education organization system]. Kyiv : Atika Publishing House, 2009. 684 p. (in Ukrainian).

2. Egorov V. V., Skibitsky E. G., Khrapchenkov V. G. Pedahohika vysshei shkoly [Higher school pedagogy]. Novosibirsk : SAFBD, 2008. 260 p. (in Russian).

3. Honcharenko S. Ukrainskyi pedahohichnyi slovnyk [Ukrainian pedagogical dictionary]. Kyiv : Lybid Publishing House, 1997. 375 p. (in Ukrainian).

4. Korotenko O. Onlain-osvita: yak zdobuvaty znannia v epokhu didzhytalizatsii [Online education: how to get knowledge in the epoch of digitalization]. URL: https://bazilik.media/onlajn-osvita-iak-zdobuvaty-znannia-v-epokhu-didzhytalizatsii/ (accessed 21 February 2021).

5. Kukharenko V. M., Rybalko O. V., Syrotenko N. H. Dystantsiine navchannia: umovy zastosuvannia. Dystantsiinyi kurs: navch. posibnyk [Distance learning: conditions of application. Distance course: textbook]. Kharkiv : NTU KhPI Torsinh Publishers, 2002. 320 p. (in Ukrainian).

6. Lukashenko I. M., Lutsenko O. L. Psykholohichni aspekty navchannia u virtualnomu seredovyshchi [Psychological Aspects of Learning in the Virtual Environment]. Platforma kiberpsykholohii Arki Group [Arki Group Cyber Psychology Platform]. URL: https://arki.group/ua/publications/psychological-aspects-of-learning-in-the-virtual-environment (accessed 3 February 2021).

7. Robert Y. V. Teoriya i metodika informatizatsii obrazovaniya (psikholoho-pedahohycheskii i tekhnolohicheskii aspekty) [Theory and methodology of informatization of education (psychological, pedagogical and technological aspects)]. Moscow : BINOM. Laboratoria Znanii, 2014. 398 p. (in Russian).

8. Sviatskyi V. V., Skrypnik O. V. Kryterii vyboru zasobiv orhanizatsii systemy dystantsiinoho navchannia [Criteria for choosing the means of organizing the distance learning system]. Trends of modern science - 2014. Materials of the X International scientific and practical conference, Sheffield, 30 of May-7 of June 2014. Sheffield : Science and Education Ltd, 2014, Volume 25. pp. 53-55 (in Ukrainian).

9. The Top 6 Trends in Education for 2020. URL: https://www.kajeet.net/the-top-6-trends-in-education-for-2020/ (accessed 26 February 2021).

10. Thorne S. L., Payne J. S. Evolutionary Trajectories, Internet-mediated Expressions and Language Education. CALICO Journal. No 22, 2005. pp. 371-397.

11. UDL System: Ukrainian Distance Learning System. URL: http://www.udl.org.ua (accessed 20 March 2021).

12. Yunsheng Zhong. A Study of Autonomy English Learning on the Internet. English Language Training. Vol. 1. No. 2, 2008. pp. 147-150 pp.

13. Zhukovska E. Top-3 systems for online education. Top-3 systemy dlia onlain navchannia. URL: https://osvita.ua/ news/71748/ (accessed 21 February 2021).

14. 27 Best Online Learning Platforms. URL: https://www.learnworlds.com/online-learning-platforms (accessed 24 March 2021). 